\title{
Archaeological and Iconographic Analysis of the Use of Funerary Personal Adornments in the Middle Kingdom of Ancient Egypt
}

\author{
Seria Yamazaki ${ }^{1,2}$ \\ ${ }^{1}$ Research Fellow of the Japan Society for the Promotion of Science (JSPS), Japan \\ ${ }^{2}$ Graduate School of Letters, Arts and Sciences, Waseda University, Tokyo, Japan
}

Copyright $\bigcirc 2018$ by authors, all rights reserved. Authors agree that this article remains permanently open access under the terms of the Creative Commons Attribution License 4.0 International License

\begin{abstract}
In the Middle Kingdom of Egypt (c. 2000$1650 \mathrm{BCE}$ ), various personal adornments were used as grave goods. This paper concentrates on the regional variability of those adornments by analyzing hundreds of tombs located in Egypt. In addition, 'ideal' assemblages and colors of personal adornments for funerary rituals will be examined through iconography such as frise d'objets, mummy masks, and anthropoid coffins. The results show that during the late Middle Kingdom, broad collars were buried with the deceased exclusively in the MemphisFaiyum region, while single-string adornments were used everywhere. Moreover, while royal broad collars resembled images seen on the body containers, non-royal broad collars were quite different. It is apparent that the ideal personal adornments were exclusive to royalty while other personal adornments were used generally, regardless of the region, for those with either royal or non-royal status.
\end{abstract}

Keywords Ancient Egypt, Middle Kingdom, Personal Adornments, Funerary Ritual

\section{Introduction}

The Middle Kingdom of ancient Egypt was a period of reformation and social change, specifically with regard to funerary customs. Moreover, belief in the afterlife became popular among commoners and they were able to associate themselves with Osiris, thereby increasing their interest in preparing for the next world. New types of grave goods were created, and also various personal adornments such as single-string necklaces and bracelets, broad collars, and girdles were buried with the deceased. In the Middle Kingdom, being identified with Osiris was very important for resurrection. Personal adornments seem to have been highly valued because the deceased could use them to present a desirable appearance for 'Osirification.' Furthermore, they could be used as amulets to protect the deceased during the journey to the next world. This study clarifies what kinds of personal adornments were needed for funerary rituals including 'Osirification,' and how widespread this practice was in the Middle Kingdom by examining the iconography and carrying out quantitative analysis of unearthed personal adornments.

The five major approaches that have been used to study ancient Egyptian personal adornments, including beads and amulets, are as follows: 1. collecting and classifying beads and amulets (e.g. [1, 2]); 2. searching for the meaning of each amulet (e.g. [3, 4]); 3. conducting quantitative analyses of the beads and amulets (e.g. $[5,6])$; 4. summarizing personal adornments by their features and diachronic changes (e.g. [7-9]); and 5. compiling case studies and discussing the use of personal adornments in burials (e.g. [10]). It can be said that studies of beads and amulets preceded the study of personal adornments. Among the study of personal adornments, approach number 4 above is the one most often used, and is useful for getting approximate information. Grajetzki's research [10] represents a more advanced stage, because it provides more specific arguments about the use of personal adornments in burials, and especially those in the Middle Kingdom. It is significant that Aldreds [7], Wilkinson [8], Andrews [9], and Grajetzki [10] used qualitative analyses, and that quantitative analyses have never been applied. As a result, general tendencies such as regional variability remain unclear. Consequently, ancient Egyptian personal adornments have not yet been thoroughly discussed. From this point of view, this paper would contribute to clarifying the exact use of personal adornments in Ancient Egypt. 


\section{Materials and Methods}

In this study, excavation reports and museum collections provided the source materials analyzed for the research.

First, the iconography was examined, mainly on three types of artifact. These artifacts include frise d'objets (based on other previous studies and museum collections), fourteen mummy masks (Table 1), and nine anthropoid coffins (Table 2), to the extent that they were recognized as being decorative. All three types of artifact are body containers. According to Cooney [11], the body containers' various functions included keeping the body of the dead intact and acting as a physical portal between the worlds of the living and the dead. It can therefore be said that the body containers were closely associated with burials and had religious purposes. Furthermore, the deceased -including females-were transformed into male deities such as Osiris by being placed in coffins [12], which suggests that body containers and personal adornments painted on them have a close connection with 'Osirification.' In other words, ideal personal adornments for funerary rituals were represented on body containers. In this analysis, the personal adornments shown on them frequently will be clarified.

Second, the actual distribution of personal adornments was investigated quantitatively. Specifically, personal adornments were classified by their forms, and by the body part on which each was worn, and then the number of tombs in which each of them had been found was tallied by region. These regions include the Memphis-Faiyum Region, Middle Egypt, and Southern Egypt (Figure 1). Personal adornments that included loose beads were observed in nearly 400 Middle Kingdom tombs distributed over the sites shown in Figure 1. Among them, the number of tombs in each region in which intact or reconstructable personal adornments were found totaled 174 in the Memphis-Faiyum Region [26-38], 53 in Middle Egypt [39-44], and 91 in Southern Egypt [25, 42, 45-57]. Though these tombs were the focus of this study, they represent the number we are able to count rather than all the tombs. It should also be borne in mind that Middle Egypt flourished almost entirely during the early Middle Kingdom. In addition to the regional variability, similarities and differences between royalty and non-royalty were identified.

Finally, the 'ideal,' as depicted in iconography, was compared to the 'reality' suggested by unearthed objects to reveal how these two differed by region or social group.

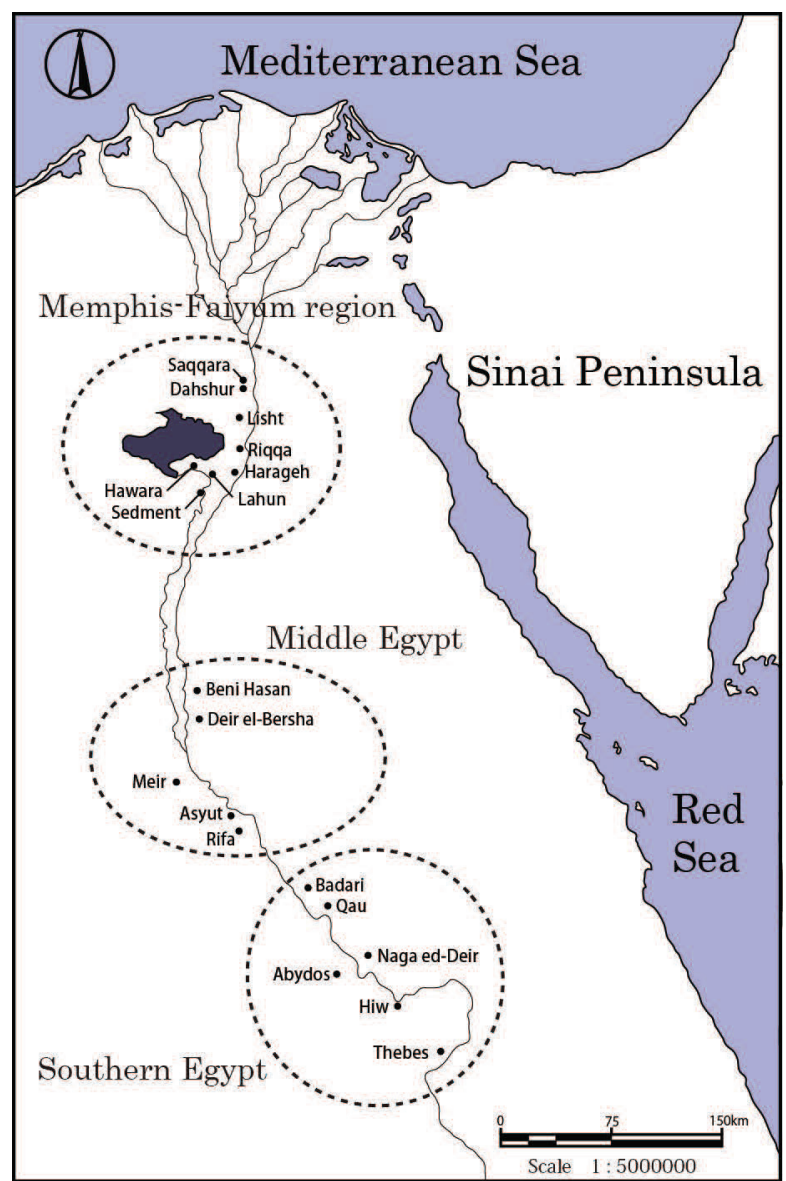

Figure 1. Map of Egypt showing the regions of Memphis-Faiyum, Middle Egypt, and Southern Egypt (Drawn by the author)

\section{Analysis of the Iconography}

\subsection{Body Containers}

\subsubsection{Frise d'objets}

The frise d'objets is one of the decorations enclosed in box coffins used mainly during the early Middle Kingdom (Figure 2). Many kinds of objects - including commodities, ritual instruments, and of course jewelry-were painted [13-15]. It has been said that these many objects would be needed in the afterlife $[16,17]$. Though various personal adornments were identified, the frequency with which they appeared is quite different. According to Willems [18], the principal items depicted in frise d'objets are broad collars with weights and broad bracelets/anklets. 
Broad collars were especially essential because frise d'objets on box coffins (CG 28024, CG 28085, CG 28094, JE 32868, JE 32869, JE 42947), which are stored in the Egyptian Museum in Cairo, always showed no single but 2-4 kinds of broad collars such as 'broad collar of silver' and 'broad collar of lapis lazuli.' It suggests that bearing various broad collars as grave goods was ideal for funeral rites. Besides broad collars and broad bracelets/anklets, sweret bead necklaces, which consist of a red barrel bead and sometimes with green/blue spherical/tubular beads, were shown on five of them (CG 28024, CG 28085, CG 28094, JE 32868, JE 32869).

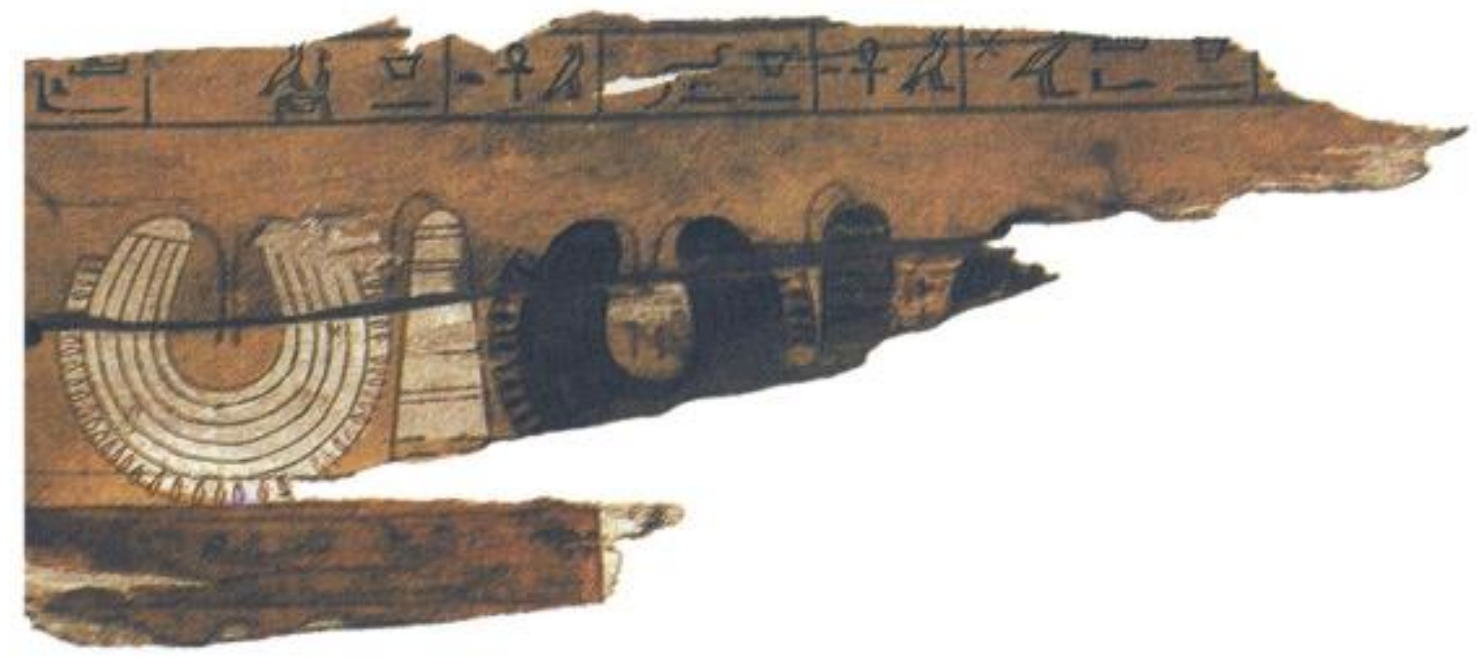

Figure 2. Fragment of frise d'objet showing broad collars with weights [81]

\subsubsection{Mummy Masks}

Three kinds of adornments — diadems, broad collars, and sweret bead necklaces — appeared on mummy masks (Figure 3 and Table 1). Broad collars were painted on all fourteen mummy masks, and sweret-bead necklaces were depicted on nine of them. Diadems appeared on mummy masks less often than broad collars and sweret-bead necklaces. In fact, diadems were only painted on the mummy masks used in Middle Egypt during the early Middle Kingdom.
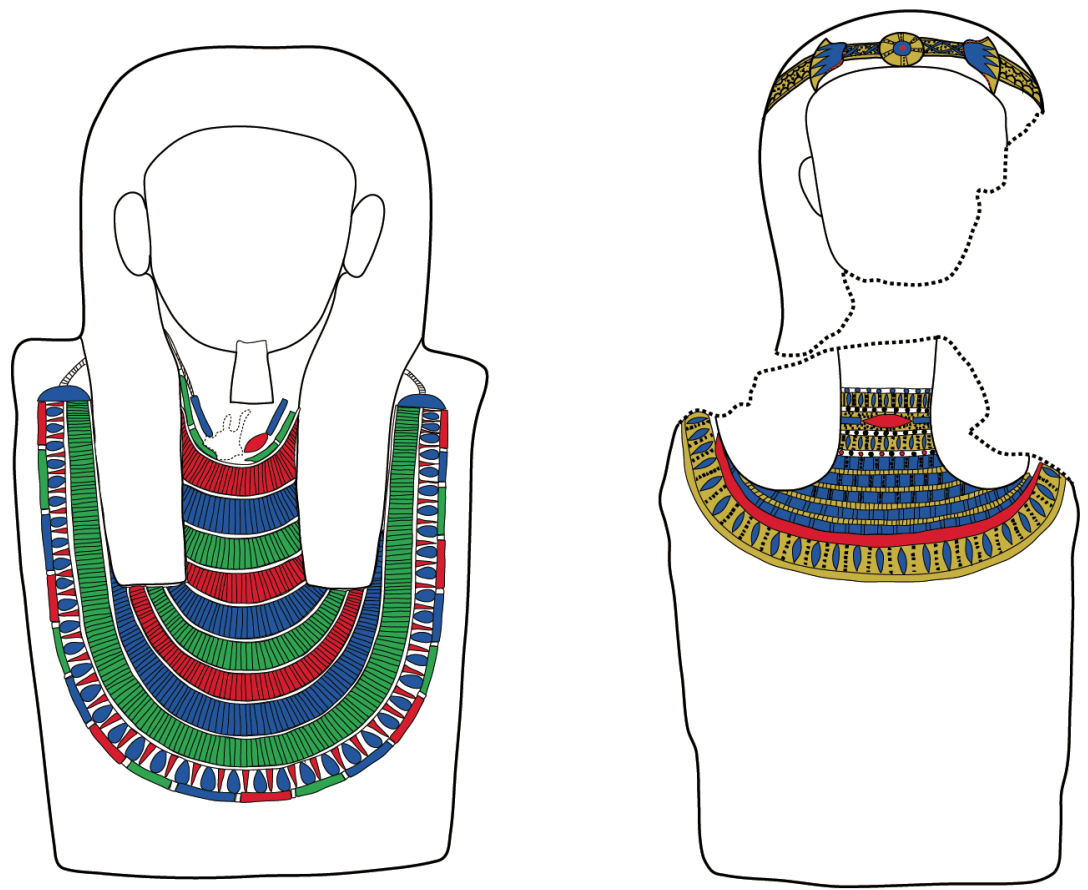

Figure 3. Examples of mummy masks showing broad collars, sweret beads, and a diadem ([62], Museum of Fine Arts, Boston, MFA 1987.54, Drawn by the author) 
Table 1. List of mummy masks analyzed in this paper

\begin{tabular}{|c|c|c|c|c|c|c|c|c|}
\hline \multirow{2}{*}{ No. } & \multirow{2}{*}{ Provenance } & \multirow{2}{*}{ Tomb no./Name } & \multirow{2}{*}{ Sex } & \multirow{2}{*}{ Period } & \multicolumn{3}{|c|}{ Represented adornments } & \multirow{2}{*}{ References } \\
\hline & & & & & Diadems & Broad collars & Sweret beads & \\
\hline 1 & Asyut & $?$ & $\mathrm{~F}$ & 11th dynasty & + & + & - & [58] \\
\hline 2 & Asyut & $?$ & M & 11th dynasty & + & + & + & [59] \\
\hline 3 & Asyut & $?$ & $?$ & $\begin{array}{c}\text { 11th dynasty or early } \\
12 \text { th dynasty }\end{array}$ & + & + & + & $\begin{array}{l}\text { [60], Museum of Fine Arts, } \\
\text { Boston (MFA1987.54) }\end{array}$ \\
\hline 4 & Asyut & $?$ & M & $\begin{array}{c}\text { 11th dynasty or early } \\
12 \text { th dynasty }\end{array}$ & + & + & + & $\begin{array}{c}\text { The Walters Art Museum } \\
(78.4)\end{array}$ \\
\hline 5 & Asyut & -/Khety-Igr & $?$ & 12th dynasty & + & + & - & $\begin{array}{c}\text { Egyptian Museum, Cairo } \\
\text { (CG36279) }\end{array}$ \\
\hline 6 & Deir el-Bersha & $\begin{array}{l}\text { tomb 10, Shaft A/ } \\
\text { Djehutynakht }\end{array}$ & $?$ & $\begin{array}{l}\text { late } 11 \text { th dynasty or } \\
\text { early } 12 \text { th dynasty }\end{array}$ & $?$ & + & $?$ & $\begin{array}{c}\text { Museum of Fine Arts, Boston } \\
\text { (MFA21.423) }\end{array}$ \\
\hline 7 & Meir & -/Iwi & $?$ & 12th dynasty & - & + & + & {$[61]$} \\
\hline 8 & near Meir & -/Senebi & M & 11th dynasty & - & + & + & $\begin{array}{c}\text { Egyptian Museum, Cairo } \\
\text { (S.R.172) }\end{array}$ \\
\hline 9 & $\begin{array}{c}\text { Saqqara, Teti } \\
\text { Pyramid cemetery }\end{array}$ & $\begin{array}{c}\text { tomb HMK30/ } \\
\text { Gemni }\end{array}$ & M & $\begin{array}{l}\text { reign of Amenemhat } \\
\text { I }\end{array}$ & - & + & + & 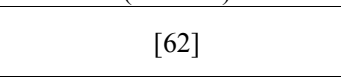 \\
\hline 10 & Saqqara & $?$ & $\mathrm{~F}$ & Middle Kingdom & - & + & + & $\begin{array}{c}\text { Egyptian Museum, Cairo } \\
\text { (S.R.178) }\end{array}$ \\
\hline 11 & $\begin{array}{c}\text { Thebes, Southern } \\
\text { Asasif }\end{array}$ & MMA 1102/Wah & M & $\begin{array}{l}\text { reign of Amenemhat } \\
\text { I }\end{array}$ & - & + & - & $\begin{array}{c}\text { [56], The Metropolitan } \\
\text { Museum of Art } \\
\text { (MMA40.3.54) }\end{array}$ \\
\hline 12 & $?$ & $?$ & $?$ & Middle Kingdom & - & + & + & $\begin{array}{c}\text { Egyptian Museum, Cairo } \\
\text { (RT24.4.26.1) }\end{array}$ \\
\hline 13 & Dahshur North & $\begin{array}{c}\text { Shaft } 42 / \\
\text { Senu }\end{array}$ & M & 13th dynasty & - & + & + & {$[63]$} \\
\hline 14 & Mirgissa & tomb $130 /$ Ibet & $\mathrm{F}$ & end of 12 th dynasty & $?$ & + & $?$ & $\begin{array}{l}\text { [64], Louvre Museum } \\
\text { (E26061) }\end{array}$ \\
\hline
\end{tabular}

\subsubsection{Anthropoid Coffins}

Personal adornments, including broad collars, sweret beads, and 'Lower Egyptian costumes,' are depicted on anthropoid coffins (Figure 4 and Table 2). Broad collars were observed on all nine anthropoid coffins, as they were on the mummy masks, and the number of sweret beads depicted was second to broad collars. The 'Lower Egyptian costumes' are one of the regalia, and consisted of belt, tail, beaded apron and hip-drape, and swallow amulet [19]. They are portrayed on two anthropoid coffins [20,21], figure 4. 'Lower Egyptian costumes' are also painted on frise d'objets. It is apparent that the personal adornments depicted on anthropoid coffins are mostly the same as on frise d'objets and mummy masks.

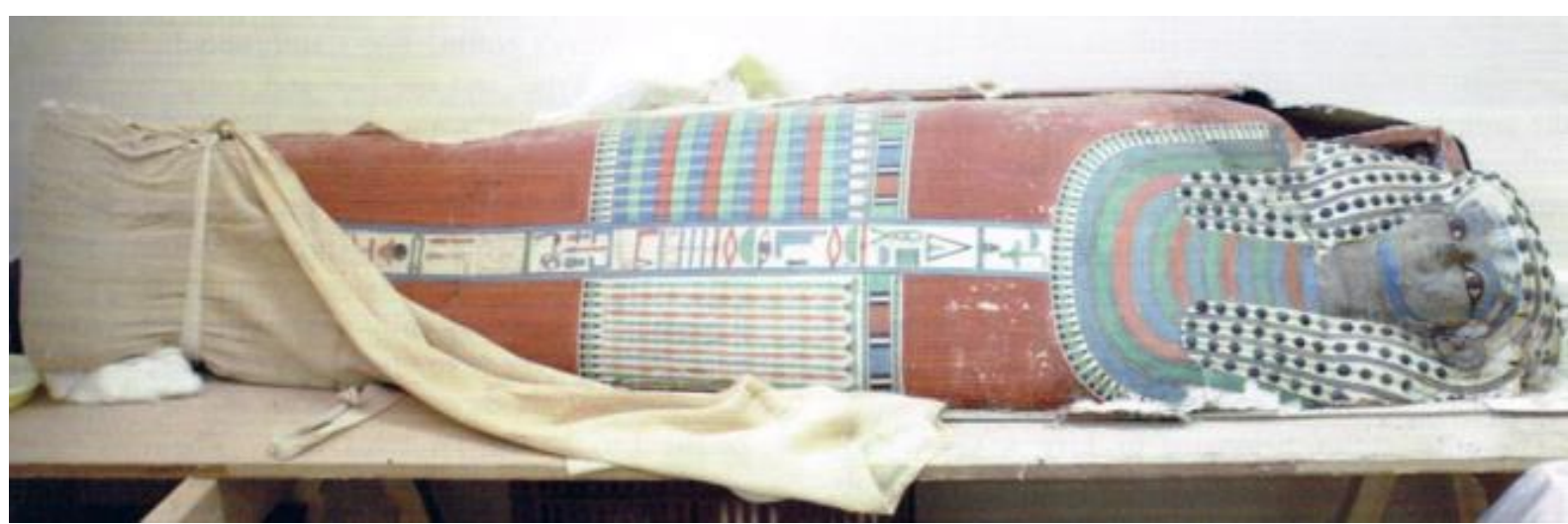

Figure 4. Example of an anthropoid coffin showing a broad collar, a sweret bead necklace, and 'Lower Egyptian costumes' [20] 
Table 2. List of anthropoid coffins analyzed in this paper

\begin{tabular}{|c|c|c|c|c|c|c|c|c|}
\hline \multirow[b]{2}{*}{ No. } & \multirow[b]{2}{*}{ Provenance } & \multirow[b]{2}{*}{ Tomb no./Name } & \multirow[b]{2}{*}{ Sex } & \multirow[b]{2}{*}{ Period } & \multicolumn{3}{|c|}{ Represented adornments } & \multirow[b]{2}{*}{ References } \\
\hline & & & & & $\begin{array}{l}\text { Broad } \\
\text { collars }\end{array}$ & $\begin{array}{l}\text { Sweret } \\
\text { beads }\end{array}$ & $\begin{array}{c}\text { 'Lower } \\
\text { Egyptian } \\
\text { costumes' }\end{array}$ & \\
\hline 1 & Dahshur North & $\begin{array}{l}\text { Shaft 65/ } \\
\text { Sebekhat }\end{array}$ & M & $\begin{array}{l}\text { late } 12 \text { th } \\
\text { dynasty }\end{array}$ & + & + & + & [20] \\
\hline 2 & Lisht North & pit 763/ Senebtisi & $\mathrm{F}$ & $\begin{array}{c}\text { reign of } \\
\text { Amenemhat III }\end{array}$ & + & + & - & [30] \\
\hline 3 & Beni Hasan & $\begin{array}{l}\text { tomb 132/ } \\
\text { Userhat }\end{array}$ & M & $\begin{array}{l}\text { reign of } \\
\text { Senusret III }\end{array}$ & + & + & - & $\begin{array}{l}\text { Fitzwilliam Museum } \\
\quad \text { (E.88.1903) }\end{array}$ \\
\hline 4 & Deir el-Bercha & tomb 14/ Sepi & M & 12th dynasty & + & + & + & [21] \\
\hline 5 & Meir & -/Hapiankhtifi & M & $\begin{array}{l}\text { middle } 12 \text { th } \\
\text { dynasty }\end{array}$ & + & - & - & $\begin{array}{c}\text { The Metropolitan Museum } \\
\text { of Art } \\
\text { (MMA12.183.11c) }\end{array}$ \\
\hline 6 & Meir & -/Nephthys & $\mathrm{F}$ & 12th dynasty & + & + & - & $\begin{array}{c}\text { The Metropolitan Museum } \\
\text { of Art } \\
\text { (MMA11.150.15b) }\end{array}$ \\
\hline 7 & Rifa & $\begin{array}{l}\text { tomb 331/ } \\
\text { Khnumhotep }\end{array}$ & M & $\begin{array}{l}\text { reign of } \\
\text { Senusret III }\end{array}$ & + & - & - & $\begin{array}{c}{[65]} \\
\text { National Museum of } \\
\text { Scotland } \\
\text { (A.1907.713.5) }\end{array}$ \\
\hline 8 & Rifa & $\begin{array}{l}\text { tomb II/ } \\
\text { Nakht-ankh }\end{array}$ & M & $\begin{array}{l}\text { late Middle } \\
\text { Kingdom }\end{array}$ & + & + & - & $\begin{array}{c}\text { [66], Manchester Museum } \\
\text { (4739) }\end{array}$ \\
\hline 9 & Rifa & $\begin{array}{c}\text { tomb II/ } \\
\text { Khnum-nakht }\end{array}$ & M & $\begin{array}{l}\text { late Middle } \\
\text { Kingdom }\end{array}$ & + & + & - & $\begin{array}{c}\text { [66], Manchester Museum } \\
(4740)\end{array}$ \\
\hline & & & & $+=$ yes, $-=n$ & $=$ unknor & & & \\
\hline
\end{tabular}

\subsection{Others}

Female figurines like 'faience fertility figurines' are one type of artifact that commonly displayed different types of jewelry [22]. 'Paddle dolls' (Figure 5 and Table 3 ) and faience fertility figurines (Figure 6 and Table 4) are both figurines of women, and closely related to dancing girls of this life [23]. The personal adornments depicted on them were very similar, with body chains and single-string adornments in particular frequently represented. Additionally, cowrie-shell girdles are frequently depicted on the faience fertility figurines. On paddle dolls, broad collars are also depicted, but they are different from the collars observed on the body containers discussed above, because paddle doll collars do not have terminals or weights. Perhaps they were not representation of broad collars but other adornments like chokers. Many personal adornments that do not appear in body containers are represented on paddle dolls and faience fertility figurines.

Further, stone sculptures have characteristics as commemorative objects. On these, several personal adornments such as single-string necklaces with a bag-shaped amulet and pectorals, which were not shown in coffins or on mummy masks, were depicted. Broad collars are also depicted though not more often than single-string necklaces with a bag-shaped amulet. 


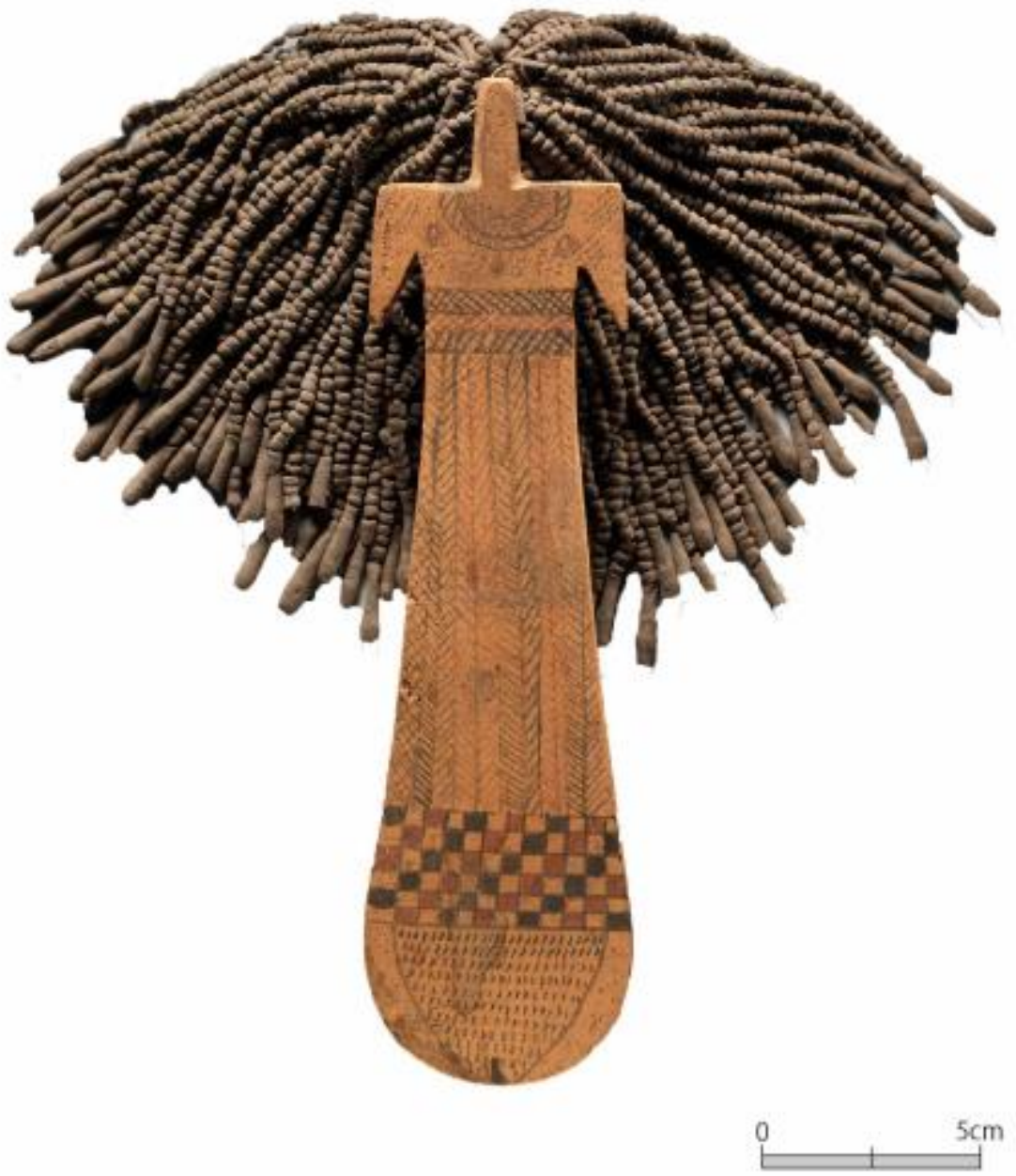

Figure 5. Example of a paddle doll (The Metropolitan Museum of Art, MMA 31.3.35a, b)
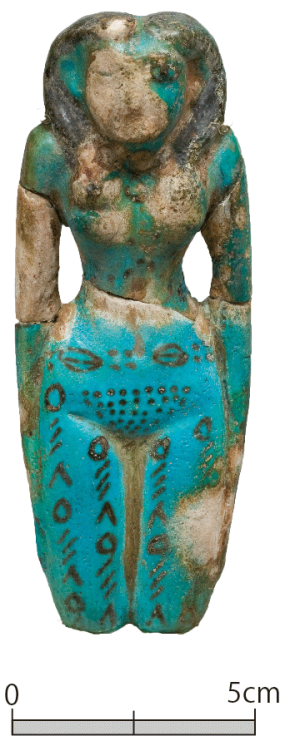

Figure 6. Example of a faience fertility figurine (The Metropolitan Museum of Art, MMA 08.200.18) 
Table 3. List of paddle dolls analyzed in this paper

\begin{tabular}{|c|c|c|c|c|c|c|c|c|c|}
\hline \multirow[b]{2}{*}{ No. } & \multirow[b]{2}{*}{ Provenance } & \multirow[b]{2}{*}{$\begin{array}{c}\text { Tomb } \\
\text { no. }\end{array}$} & \multirow[b]{2}{*}{ Period } & \multicolumn{4}{|c|}{ Represented adornments } & \multirow[b]{2}{*}{$\begin{array}{l}\text { Tattoo or } \\
\text { painting }\end{array}$} & \multirow[b]{2}{*}{ References } \\
\hline & & & & $\begin{array}{c}\text { Single-string } \\
\text { necklaces }\end{array}$ & $\begin{array}{l}\text { Collars without } \\
\text { terminals and } \\
\text { weights }\end{array}$ & Bracelets & $\begin{array}{l}\text { Body } \\
\text { chains }\end{array}$ & & \\
\hline 1 & $\begin{array}{c}\text { Thebes, } \\
\text { Sheikh Farag }\end{array}$ & S.F. 8 & 11 th dynasty & - & 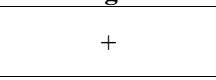 & - & $?$ & $?$ & $\begin{array}{l}\text { Museum of Fine Arts, } \\
\text { Boston (MFA13.3567) }\end{array}$ \\
\hline 2 & $\begin{array}{c}\text { Thebes, } \\
\text { Sheikh Farag }\end{array}$ & S.F. 12 & 11 th dynasty & - & + & $?$ & $?$ & $?$ & $\begin{array}{l}\text { Museum of Fine Arts, } \\
\text { Boston (MFA13.3603) }\end{array}$ \\
\hline 3 & $\begin{array}{l}\text { Thebes, } \\
\text { Asasif }\end{array}$ & 816 & 11th dynasty & - & + & - & + & + & $\begin{array}{l}\text { The Metropolitan } \\
\text { Museum of Art } \\
\text { (MMA31.3.35a, b) }\end{array}$ \\
\hline 4 & $\begin{array}{c}\text { Thebes, } \\
\text { Asasif }\end{array}$ & 816 & 11 th dynasty & + & - & - & $?$ & + & $\begin{array}{l}\text { The Metropolitan } \\
\text { Museum of Art } \\
\text { (MMA31.3.37a, b) }\end{array}$ \\
\hline 5 & $\begin{array}{l}\text { Thebes, } \\
\text { Asasif }\end{array}$ & 816 & 11 th dynasty & - & - & - & + & $?$ & $\begin{array}{l}\text { The Metropolitan } \\
\text { Museum of Art } \\
(\text { MMA31.3.36a, b) }\end{array}$ \\
\hline 6 & $\begin{array}{l}\text { Thebes, } \\
\text { Asasif }\end{array}$ & 816 & 11th dynasty & - & + & - & $?$ & + & $\begin{array}{c}\text { [67], Egyptian } \\
\text { Museum, Cairo (JE } \\
56274)\end{array}$ \\
\hline 7 & $\begin{array}{l}\text { Thebes, } \\
\text { Asasif }\end{array}$ & 813 & 11 th dynasty & - & + & $?$ & + & - & $\begin{array}{l}\text { The Metropolitan } \\
\text { Museum of Art } \\
\text { (MMA31.3.38) }\end{array}$ \\
\hline 8 & $\begin{array}{l}\text { Thebes, } \\
\text { Asasif }\end{array}$ & 818 & 11th dynasty & - & + & - & - & + & $\begin{array}{l}\text { The Metropolitan } \\
\text { Museum of Art } \\
\text { (MMA31.3.43) }\end{array}$ \\
\hline 9 & $\begin{array}{l}\text { Thebes, } \\
\text { Asasif }\end{array}$ & 839 & 11th dynasty & + & - & $?$ & + & $?$ & $\begin{array}{l}\text { The Metropolitan } \\
\text { Museum of Art } \\
\text { (MMA31.3.45) }\end{array}$ \\
\hline 10 & $\begin{array}{l}\text { Thebes, } \\
\text { Khokha }\end{array}$ & 828 & 11th dynasty & - & + & + & $?$ & $?$ & $\begin{array}{l}\text { The Metropolitan } \\
\text { Museum of Art } \\
\text { (MMA15.10.90) }\end{array}$ \\
\hline 11 & $?$ & $?$ & $\begin{array}{l}\text { early Middle Kingdom (or } \\
\text { First Intermediate Period) }\end{array}$ & - & + & - & $?$ & $?$ & $\begin{array}{c}\text { British Museum } \\
(\text { EA6459) }\end{array}$ \\
\hline 12 & Thebes & $?$ & early Middle Kingdom & + & - & + & $?$ & $?$ & $\begin{array}{c}\text { National Museum of } \\
\text { Scotland } \\
\text { (A.1911.284) } \\
\end{array}$ \\
\hline 13 & $?$ & $?$ & Middle Kingdom & - & + & $(+)$ & + & + & $\begin{array}{c}\text { Brooklyn Museum } \\
(37.100)\end{array}$ \\
\hline 14 & $?$ & $?$ & Middle Kingdom & - & + & + & + & + & $\begin{array}{c}\text { Brooklyn Museum } \\
(37.101)\end{array}$ \\
\hline 15 & $?$ & $?$ & Middle Kingdom & - & - & - & + & + & $\begin{array}{c}\text { Brooklyn Museum } \\
(37.102)\end{array}$ \\
\hline 16 & $?$ & $?$ & Middle Kingdom & + & - & - & - & - & $\begin{array}{c}\text { Brooklyn Museum } \\
\quad(37.104)\end{array}$ \\
\hline 17 & $?$ & $?$ & Middle Kingdom & - & + & $(+)$ & + & + & $\begin{array}{c}\text { Brooklyn Museum } \\
(37.105)\end{array}$ \\
\hline 18 & $?$ & $?$ & Middle Kingdom & + & - & + & + & + & $\begin{array}{c}\text { Brooklyn Museum } \\
(16.84)\end{array}$ \\
\hline 19 & $?$ & $?$ & Middle Kingdom & $?$ & $?$ & + & + & $?$ & {$[68]$} \\
\hline 20 & $?$ & $?$ & Middle Kingdom & $?$ & $?$ & + & $?$ & $?$ & [69] \\
\hline 21 & $?$ & $?$ & Middle Kingdom & - & + & $?$ & $?$ & $?$ & {$[70]$} \\
\hline 22 & $?$ & $?$ & Middle Kingdom & + & - & + & $?$ & $?$ & $\begin{array}{l}\text { Museum of Fine Arts, } \\
\text { Boston (MFA72.4287) }\end{array}$ \\
\hline 23 & $?$ & $?$ & Middle Kingdom & - & + & - & + & + & $\begin{array}{l}\text { Museum of Fine Arts, } \\
\text { Boston (MFA13.5100) }\end{array}$ \\
\hline 24 & $?$ & $?$ & Middle Kingdom & + & - & + & + & - & $\begin{array}{l}\text { Fitzwilliam Museum } \\
\text { (E.50.1946) }\end{array}$ \\
\hline 25 & $?$ & $?$ & Middle Kingdom & + & - & + & + & - & $\begin{array}{l}\text { Fitzwilliam Museum } \\
\text { (E.49.1946) }\end{array}$ \\
\hline 26 & $?$ & $?$ & Middle Kingdom & $?$ & $?$ & $(+)$ & + & $(+)$ & $\begin{array}{c}\text { Petrie Museum } \\
\text { (UC59277) }\end{array}$ \\
\hline
\end{tabular}


Table 4. List of 'faience fertility figurines' analyzed in this paper

\begin{tabular}{|c|c|c|c|c|c|c|c|c|c|c|}
\hline \multirow[b]{2}{*}{ No. } & \multirow[b]{2}{*}{ Provenance } & \multirow{2}{*}{$\begin{array}{c}\text { Tomb } \\
\text { no./Name }\end{array}$} & \multirow[b]{2}{*}{ Period } & \multicolumn{5}{|c|}{ Represented adornments } & \multirow[b]{2}{*}{ Tattoo } & \multirow[b]{2}{*}{ References } \\
\hline & & & & $\begin{array}{l}\text { Single-string } \\
\text { necklaces }\end{array}$ & $\begin{array}{l}\text { Cowrie-shell } \\
\text { girdles }\end{array}$ & $\begin{array}{c}\text { Single-string } \\
\text { bracelets }\end{array}$ & $\begin{array}{c}\text { Broad } \\
\text { bracelets }\end{array}$ & $\begin{array}{l}\text { Body } \\
\text { chains }\end{array}$ & & \\
\hline 1 & Lisht South & pit 3/Hepy & early 12 th dynasty & + & - & - & + & - & - & [71] \\
\hline 2 & Lisht South & pit 3/Hepy & early 12 th dynasty & + & + & - & + & - & + & [72] \\
\hline 3 & Lisht South & pit 3/Hepy & early 12 th dynasty & + & - & $?$ & $?$ & - & - & $\begin{array}{l}\text { [73], The Metropolitan } \\
\text { Museum of Art } \\
\text { (MMA34.1.125) }\end{array}$ \\
\hline 4 & Lisht South & $\begin{array}{l}\text { pit 3/ } \\
\text { Hepy }\end{array}$ & early 12 th dynasty & + & - & + & $(+)$ & - & - & [74] \\
\hline 5 & Lisht North & pit $752 /-$ & $\begin{array}{l}\text { late } 12 \text { th dynasty } \\
\text { or early 13th } \\
\text { dynasty }\end{array}$ & + & + & $?$ & - & + & + & $\begin{array}{l}\text { The Metropolitan } \\
\text { Museum of Art } \\
\text { (MMA08.200.18) }\end{array}$ \\
\hline 6 & Lisht North & pit $885 /-$ & $\begin{array}{l}\text { middle 13th } \\
\text { dynasty }\end{array}$ & $?$ & $?$ & $?$ & $?$ & $?$ & + & $\begin{array}{l}\text { The Metropolitan } \\
\text { Museum of Art } \\
\text { (MMA22.1.180) }\end{array}$ \\
\hline 7 & Lisht & $?$ & $?$ & + & - & + & + & - & - & {$[75]$} \\
\hline 8 & Lahun & $?$ & 12th dynasty & $(+)$ & $(+)$ & - & $(+)$ & - & + & $\begin{array}{l}\text { Petrie Museum } \\
\text { (UC16725) }\end{array}$ \\
\hline 9 & $\begin{array}{c}\text { 'Kahun' } \\
\text { (dwelling site) }\end{array}$ & - & 12th dynasty & $?$ & + & - & + & - & + & [76] \\
\hline 10 & $\begin{array}{c}\text { 'Kahun' } \\
\text { (dwelling site) }\end{array}$ & - & 12th dynasty & $?$ & + & + & - & - & + & [77] \\
\hline 11 & Thebes, Asasif & $\begin{array}{c}\text { TT316/ } \\
\text { Neferhotep }\end{array}$ & 12th dynasty & + & + & $?$ & + & + & + & $\begin{array}{l}\text { [78], Egyptian Museum, } \\
\text { Cairo (JE 47710) }\end{array}$ \\
\hline 12 & $?$ & $?$ & $\begin{array}{l}\text { 12th dynasty or } \\
\text { early 13th dynasty }\end{array}$ & + & + & - & - & + & + & $\begin{array}{c}\text { Brooklyn Museum } \\
(44.226)\end{array}$ \\
\hline 13 & Thebes & $5 /-$ & 13th dynasty & $?$ & $(+)$ & $?$ & $?$ & $?$ & $?$ & $\begin{array}{l}\text { Manchester Museum } \\
(1787)\end{array}$ \\
\hline 14 & Thebes, Asasif & 809/- & $\begin{array}{l}\text { Middle Kingdom } \\
\text { or New Kingdom }\end{array}$ & $?$ & + & $?$ & $?$ & $?$ & + & $\begin{array}{c}\text { [79], The Metropolitan } \\
\text { Museum of Art } \\
\text { (MMA14.1.416) }\end{array}$ \\
\hline 15 & Thebes, Asasif & $828 /-$ & $\begin{array}{l}\text { Middle Kingdom } \\
\text { or New Kingdom }\end{array}$ & $?$ & + & $?$ & $?$ & $?$ & + & $\begin{array}{l}\text { Morris 2011, 79; The } \\
\text { Metropolitan Museum of } \\
\text { Art (MMA15.10.93) }\end{array}$ \\
\hline 16 & $\begin{array}{l}\text { Western } \\
\text { Thebes }\end{array}$ & $?$ & Middle Kingdom & - & + & $?$ & $?$ & - & + & $\begin{array}{c}\text { British Museum } \\
(\text { EA52863 })\end{array}$ \\
\hline 17 & $?$ & $?$ & Middle Kingdom & + & + & + & + & + & + & $\begin{array}{l}\text { Louvre Museum } \\
\quad(\text { E10942) }\end{array}$ \\
\hline 18 & $?$ & $?$ & Middle Kingdom & + & + & + & + & + & + & $\begin{array}{c}\text { [80], Ägyptisches } \\
\text { Museum, Berlin inv. no. } \\
9583\end{array}$ \\
\hline
\end{tabular}

\subsection{Ideal Personal Adornments for Funerary Rituals}

The analyses confirmed the different kinds of personal adornments depicted in body containers and other artifacts. In other words, the personal adornments depicted depended on the nature of each artifact. Furthermore, the personal adornments depicted on the body containers can be regarded as ideal items for funerary rituals including the purpose of 'Osirification.' It is very obvious that of these, the broad collar was the most important item. Broad collars were painted on mummy masks and anthropoid coffins in a polychrome style, often using red, blue, and green colors to imitate the semi-precious stones carnelian, lapis lazuli, and turquoise respectively. It was also important to show broad collars made of various materials in frise d'objets. Based on our findings, we are now able to reconstruct an ideal set of personal adornments for funerary rituals (Figure 7): polychrome broad collars, broad bracelets/anklets, sweret beads, and 'Lower Egyptian costumes.' Broad bracelets/anklets were frequently shown together with broad collars in the frise d'objets. The depiction of a sweret-bead necklace was common to the frise d'objets, mummy masks, and anthropoid coffins. Finally, 'Lower Egyptian costumes' were shown in the frise d'objets and anthropoid coffins. 


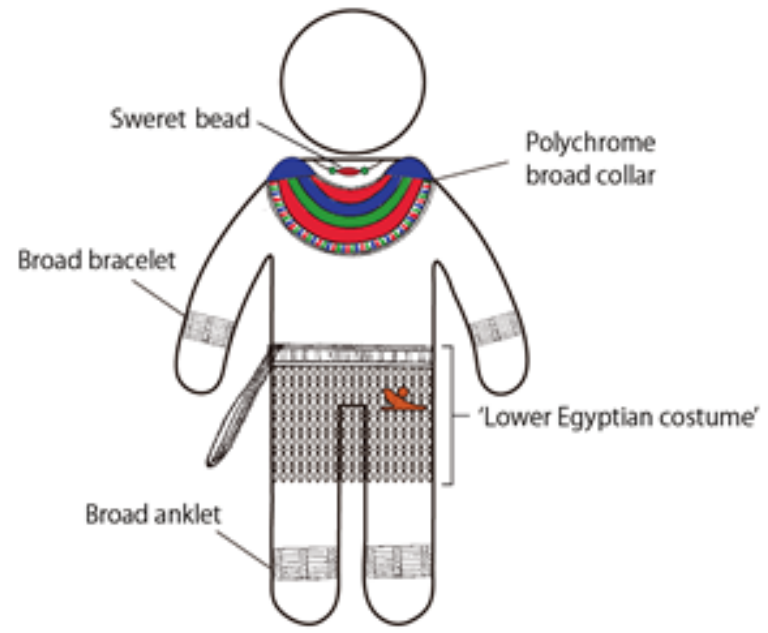

Figure 7. Reconstruction of the ideal personal adornments for funerary rituals (Drawn by the author)

Other personal adornments like cowrie-shell girdles and pectorals painted on artifacts other than body containers seem to have been regarded as adornments that signified the deceased's identity - including gender and social class. In fact, cowrie-shell girdles have been considered as amulets protecting females [24], and are mainly found in female tombs. Therefore, it is suggested that personal adornments used as grave goods in the Middle Kingdom could be categorized into two main groups (Figure 8): personal adornments needed for the process of 'Osirification,' and personal adornments that confirmed the identity of the deceased.

This categorization is not only evident in iconography but also in archaeological finds. For instance, a mummy named Wah was buried in Thebes during the early Middle Kingdom and several personal adornments were found when this mummy was unwrapped. They were single-string necklaces and bracelets, a finger ring, broad bracelets and anklets, a broad collar, and a sweret bead [25]. However, they were not placed in the same layer of linen bandages. According to the report, the broad bracelets and anklets, broad collar, and sweret bead were placed in the layer that was closer to the body of the deceased than the other personal adornments. In this study, broad bracelets and anklets, broad collars, and sweret beads were reconstructed as the ideal personal adornments for funerary rituals. Therefore, $W a h$ 's personal adornments may have been intentionally put in the bandages separately.

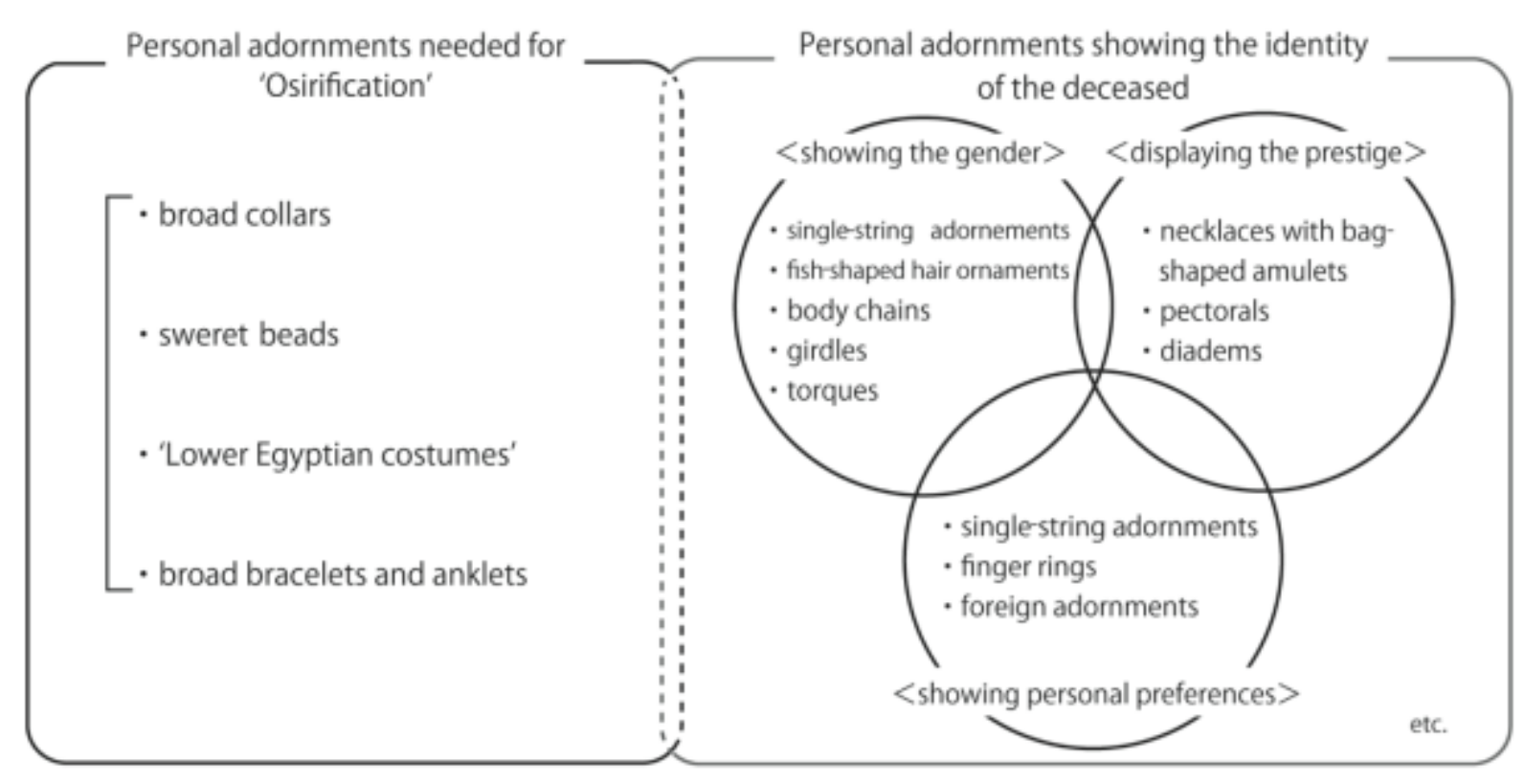

Figure 8. Categorization of personal adornments in the Middle Kingdom 


\section{Analysis of the Excavated Personal Adornments}

\subsection{Regional Variability}

Middle Kingdom personal adornments excavated from tombs can be classified into twelve types, as shown in Figure 9. Table 5 summarizes the number of tombs in each region [26-38], [39-44], [25, 42, 45-57] from which personal adornments were excavated. As a result, it is clear that single-string adornments were those most often found in tombs, followed by broad collars. We now examine these two types of adornments in more detail.

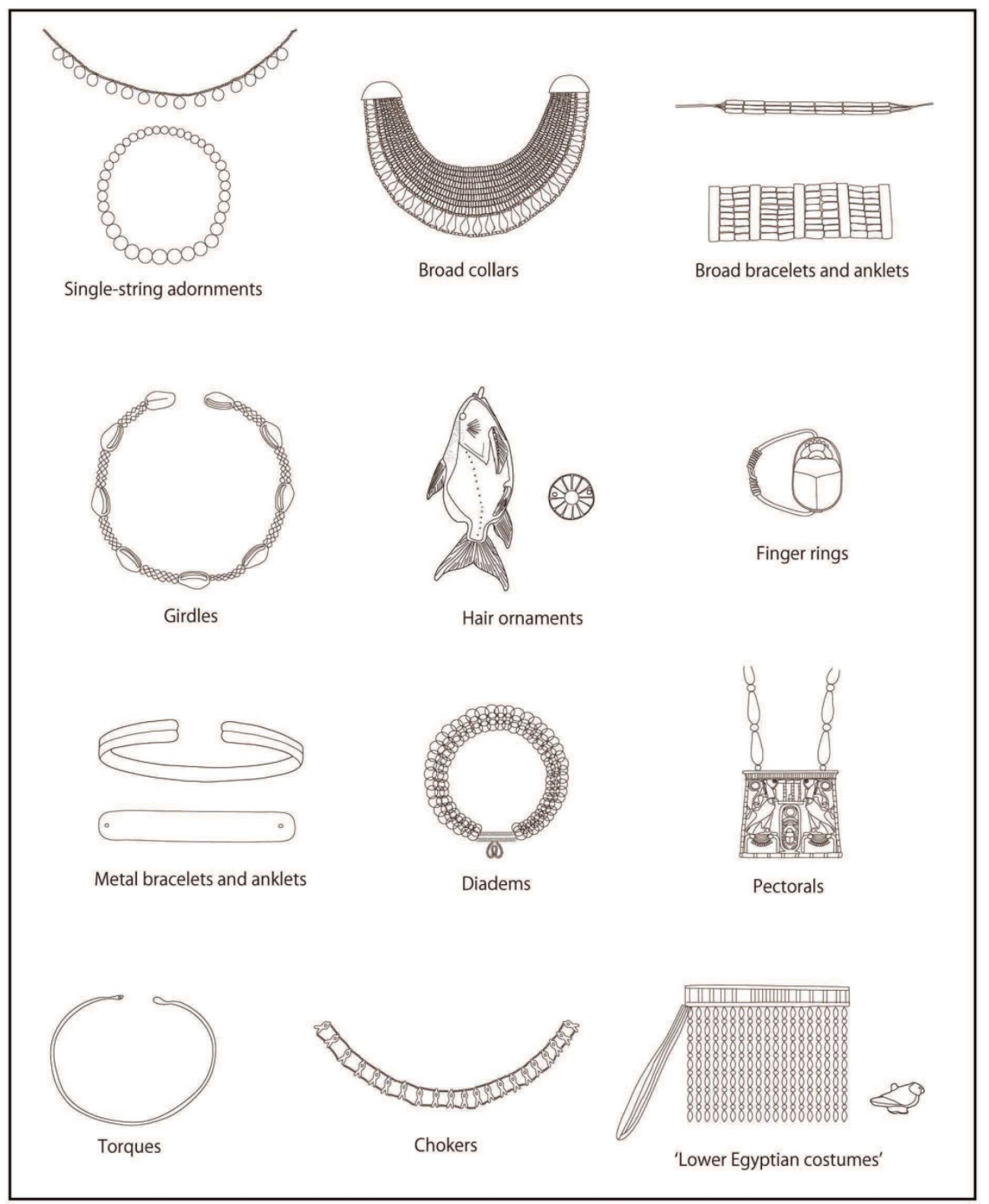

Figure 9. Classification of personal adornments of the Middle Kingdom (Drawn by the author)

Table 5. Number of tombs in which each type of personal adornment was found

\begin{tabular}{ccccccccccccccccc}
\hline & $\begin{array}{c}\text { Single string } \\
\text { adornments }\end{array}$ & Broad collars & $\begin{array}{c}\text { Broad bracelets } \\
\text { and anklets }\end{array}$ & Girdles & Hair ornaments & Finger rings & Metal bracelets & Diadems & Pectorals & Torques & Chokers & $\begin{array}{c}\text { 'Lower Egyptian } \\
\text { costumes' }\end{array}$ \\
\hline $\begin{array}{c}\text { Memphis-Faiyum } \\
\text { Region }\end{array}$ & 120 & 72 & 25 & 16 & 9 & 4 & 5 & 7 & 6 \\
\hline Middle Egypt & 44 & 11 & 1 & 2 & 2 & 4 & 2 & 0 & 0 & 0 & 0 \\
\hline Southern Egypt & 87 & 3 & 3 & 6 & 4 & 5 & 6 & 0 & 0 & 5 & 0 \\
\hline
\end{tabular}


Single-string adornments often consisted of spherical beads or barrel beads, so for the purposes of this study, those beads are considered parts of the single-string adornments. This kind of personal adornment was the one most frequently buried with the deceased in all regions through the Middle Kingdom. The raw materials used for these beads varied and included faience, gold, silver, and many kinds of semi-precious stones such as carnelian, lapis lazuli, and turquoise. In the Memphis-Faiyum Region and Southern Egypt, the number of tombs with beads for single-string adornments made of gold, silver, and semi-precious stones exceeded the number of tombs with beads made of faience. Even in Middle Egypt, the number of tombs with beads made of gold, silver, and semi-precious stones was almost same as the number of tombs with beads made of faience. Gold and silver were the materials most frequently used in Southern Egypt.

Broad collars were found almost exclusively in the Memphis-Faiyum Region from mid-dynasty 12 onward. Middle Egypt was second to the Memphis-Faiyum Region, beginning with the early Middle Kingdom tombs. A few broad collars were found in Southern Egypt, and they were in early Middle Kingdom tombs. This tendency can also be observed with regard to broad bracelets/anklets, which were found almost exclusively in the Memphis-Faiyum Region.

In summary, with regard to the regional distribution of personal adornments, single-string adornments made of various materials were found in the largest number of tombs in all regions throughout the Middle Kingdom. Broad collars and broad bracelets/anklets were found almost exclusively in the Memphis-Faiyum Region, especially from the mid-dynasty 12 onward.

\subsection{Similarities and Differences between Royalty and Non-Royalty}

As already noted, broad collars were found almost exclusively in the Memphis-Faiyum Region. However, there are differences between royal and non-royal broad collars. Royal broad collars are made of various semi-precious stones, gold, and silver, while those for non-royalty, such as the people who were buried in Harageh and Riqqeh [28, 29], were almost always made of faience. Moreover, weights have only been found in royal tombs. These differences lead us to compare the iconography. In short, royal broad collars resembled those on body containers, while non-royal broad collars were quite different.

There were also differences between the 'Lower Egyptian costumes' of royalty and non-royalty. During the late Middle Kingdom, the real 'Lower Egyptian costumes' were exclusively buried with royalty, or with people who were very close to them. Although non-royalty could use the anthropoid coffins on which the 'Lower Egyptian costumes' were painted, they could not afford the 'Lower Egyptian costumes' as actual grave goods.

Finally, amulets such as shell-shaped pendants and amulet cases were made of gold or silver, and were used by both royalty and non-royalty as burial goods. Furthermore, as we saw above, it is evident that the raw materials used for single-string adornments varied equally in all regions, and this variation was common to both royalty and non-royalty. This suggests that limits on the types of raw materials used for broad collars were not applied to other ornaments.

In brief, many personal adornments, including their raw materials, were common to royalty and non-royalty, though there were differences between specific personal adornments, such as broad collars and 'Lower Egyptian costumes.' Additionally, royal personal adornments resembled the iconography on the body containers.

\section{Comparison between the 'Ideal' and 'Reality' of Personal Adornments for Funerary Rituals}

We will now compare the iconography and the unearthed objects. As has already been discussed, the personal adornments represented on body containers are considered the ideal grave goods for 'Osirification.' These ideal personal adornments and their actual distribution-especially from mid-dynasty 12 onward - are compared in Figure 10 below. Please note that sweret beads are not considered here because of the near-impossibility of positively identifying beads found in excavations as being sweret beads or not.

Figure 10 demonstrates the actual use of both groups of personal adornments, which were needed for 'Osirification' and also to establish the identity of the deceased. It is obvious that the reality of royalty in the Memphis-Faiyum Region was the one most similar to the ideal, because besides personal adornments indicating identity, all the types of personal adornments needed for 'Osirification' are included. Secondly, non-royalty in the Memphis-Faiyum Region are similar to the ideal in terms of broad collars and broad bracelets, but the broad collars are not polychrome. Finally, the reality in Middle Egypt and Southern Egypt was quite different from the ideal, though they could have personal adornments showing the identity of the deceased made of semi-precious stones, gold, and silver. 


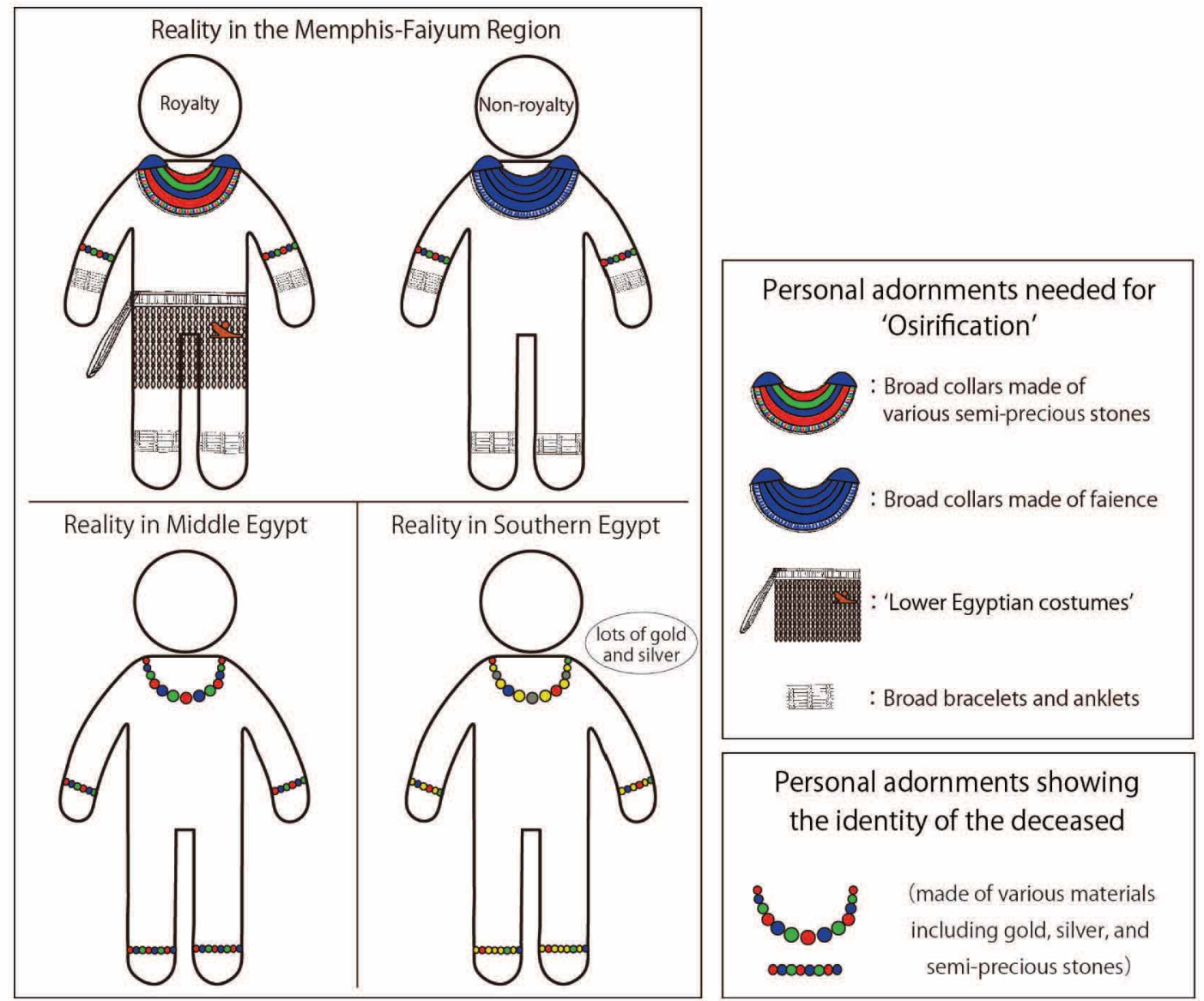

Figure 10. Actual use of personal adornments needed for 'Osirification' and to show the identity of the deceased from mid-dynasty 12 onward (Drawn by the author)

\section{Conclusions}

In this paper, the personal adornments represented on body containers were premised on their being the ideal grave goods for 'Osirification,' and they were compared to unearthed personal adornments. As a result, it is apparent that the ideal personal adornments were exclusive to royalty. On the other hand, personal adornments that were not frequently depicted on body containers were used generally, regardless of the region, for those with either royal or non-royal status. Moreover, there were no limits placed on the materials used. This suggests that royalty intentionally differentiated themselves from non-royalty in regard to the specific personal adornments that were especially important for 'Osirification.' Is it possible that royalty tried to maintain their power through those differences? This study did not gather enough information to address this argument, and more detailed analyses of other grave goods need to be conducted in the future.

\section{Acknowledgements}

This work was supported by a Japan Society for the
Promotion of Science (JSPS) Grant-in-Aid for JSPS Fellows (No. 17J02366).

\section{REFERENCES}

[1] W. M. F. Petrie. Amulets, Aris \& Phillips and Joel L. Malter, London, 1914.

[2] Xia Nai Ancient Egyptian Beads, Springer, London, 2014.

[3] C. Andrews. Amulets of Ancient Egypt, British Museum Press, London, 1994.

[4] A. Golani. 'Cowrie Shells and Their Imitations as Ornamental Amulets in Egypt and the Near East', in A. Golani and Z. Wygnanska (eds.) Polish Archaeology in the Mediterranean, Special Study: Beyond Ornamentation. Jewelry as an Aspect of Material Culture in the Ancient Near East, Polish Centre of Mediterranean Archaeology, University of Warsaw, Wydawnictwa Uniwersytetu Warszawskiego, pp.71-94, 2014.

[5] A. Boyce. 'Collar and Necklace Design at Amarna: A Preliminary Study of Faience Pendants', in B. J. Kemp (ed.) Amarna Report VI, Cambridge University Press, London, pp.336-371, 1995. 
[6] V. Gashe. 'An Analysis of the Use of Beads and Amulets as a Mortuary Item in Protodynastic Graves at the Upper Egyptian Site of Badari', in K. Griffin (ed.) Current Research in Egyptology 2007: Proceeding of the Eighteenth Annual Symposium, Oxbow Books, Oxford, pp.71-82, 2007.

[7] C. Aldred. Jewels of the Pharaohs, Thames and Hudson, London, 1971.

[8] A. Wilkinson. Ancient Egyptian Jewellery, Methuen, London, 1971.

[9] C. Andrews. Ancient Egyptian Jewellery, British Museum Publications, London, 1990.

[10] W. Grajetzki. Tomb Treasures of the Middle Kingdom: The Archaeology of Female Burials, University of Pennsylvania Press, Philadelphia, 2014.

[11] K.M. Cooney. 'Coffins, Cartonnage, and Sarcophagi', in M. K. Hartwig (ed.) A Companion to Ancient Egyptian Art, Wiley Blackwell, West Sussex, pp.269-292, 2015: 270271.

[12] K.M. Cooney. 'Gender Transformation in Death: A Case Study of Coffins from Ramesside Period Egypt', Near Eastern Archaeology 73, pp.224-237, 2010: 224.

[13] G. Jéquier. Les Frises d'objets des sarcophages du Moyen-Empire, Imprimerie de l'institut Français, Cairo, 1921.

[14] P. Lacau. Sarcophages antérieurs au Nouvel Empire vol.I, Imprimerie de l'institut Français, Cairo, 1904.

[15] P. Lacau. Sarcophages antérieurs au Nouvel Empire vol.II, Imprimerie de l'institut Français, Cairo, 1906.

[16] C. Andrews. Egyptian Mummies, British Museum Press, London, 1984: 41.

[17] S. Snape. Ancient Egyptian tombs: the Culture of Life and Death, Wiley Blackwell, Oxford, 2011: 143.

[18] H. Willems. Chest of Life: A Study of the Typology and Conceptual Development of Middle Kingdom Standard Class Coffins, Orientaliste Leuven, Leiden, 1988: 215-224.

[19] D. C. Patch. 'A "Lower Egyptian" Costume: Its Origin, Development, and Meaning', Journal of the American Research Center in Egypt 32, pp.93-116, 1995.

[20] M. Baba, and S. Yoshimura. 'Dahshur North: Intact Middle and New Kingdom Coffins', Egyptian Archaeology 37 (Autumn), pp.9-12, 2010: 11.

[21] P. Lacau. Sarcophages antérieurs au Nouvel Empire vol.I, Imprimerie de l'institut Français, Cairo, 1904: 199-200.

[22] W. Grajetzki. Tomb Treasures of the Middle Kingdom: The Archaeology of Female Burials, University of Pennsylvania Press, Philadelphia, 2014: 115-116.

[23] E. F. Morris. 'Paddle Dolls and Performance', Journal of the American Research Center in Egypt 47, pp.71-103, 2011.

[24] C. Andrews. Amulets of Ancient Egypt, British Museum Press, London, 1994: 42.

[25] H. E. Winlock. 'The Mummy of Wah Unwrapped', Bulletin of the Metropolitan Museum of Art 33, pp. 72-76, 1940.

[26] J. de Morgan. Fouilles a Dahchour, Mars-Juin 1894, Adolphe Holzhausen, Vienna, 1895.

[27] J. de Morgan. Fouilles a Dahchour 1895, Adolphe Holzhausen, Vienna, 1903.

[28] R. Engelbach. Riqqeh and Memphis VI, British School of Archaeology in Egypt and Egyptian Research Account, London, 1915.

[29] R. Engelbach. Harageh, British School of Archaeology in Egypt and Egyptian Research Account, London, 1923.

[30] A. C. Mace and H. E. Winlock. The Tomb of Senebtisi at Lisht, Metropolitan Museum of Art, New York, 1916.

[31] G. Brunton. Lahun I: The Treasure, British School of Archaeology in Egypt University College, London, 1920.

[32] W. M. F. Petrie, G. Brunton and M. A. Murray. Lahun II, British School of Archaeology in Egypt University College, London, 1923.

[33] C. M. Firth and B. Gunn. Teti Pyramid Cemeteries, Imprimerie de l'institut Français, Cairo, 1926.

[34] A. Lansing and W. C. Hayes. 'The Egyptian Expedition: The Excavations at Lisht', The Metropolitan Museum of Art Bulletin 29, pp.4-41, 1934.

[35] H. E. Winlock. The Treasure of El Lahun, Metropolitan Museum of Art, New York, 1934.

[36] N. Farag and Z. Iskander. The Discovery of Neferuptah, General Organization for Government Printing Offices, Cairo, 1971.

[37] D. Arnold. The Pyramid Complex of Senwosret I: The South Cemeteries of Lisht III, The Stinehour Press, New York, 1992.

[38] M. Baba, and S. Yoshimura. 'Ritual Activities in Middle Kingdom Egypt: A View from Intact Tombs Discovered at Dahshur North', in M. Bárta, F. Coppens, and J. Krejcí (eds.) Abusir and Saqqara in the Year 2010/1, Czech Institute of Egyptology of Charles University, Prague, pp.158-170, 2011.

[39] A. B. Kamal. 'Report sur les fouilles executées à Dê̂e-el-Bershé', Annales du Service des Antiquités de l' Égypte 2, pp.206-22, 1901.

[40] J. Garstang. Burial Customs of Ancient Egypt: As Illustrated by Tombs of the Middle Kingdom, A Report of Excavations made in the Necropolis of Beni Hassan during 1902-3-4, Constable \& co, London, 1907.

[41] W. M. F. Petrie. Gizeh and Rifeh, Aris \& Phillips and Joel L. Malter, London, 1907.

[42] W. C. Hayes. The Scepter of Egypt I: From the Earliest Times to the End of the Middle Kingdom, Plantin Press, New York, 1953.

[43] S. D'Auria, P. Lacovara, and C. H. Roehrig. Mummies and Magic: the Funerary Arts of Ancient Egypt, MFA Publications, Boston, 1988.

[44] M. El-Khadragy. 'Some Significant Features in the Decoration of the Chapel of Iti-ibi-iqer at Asyut', Studien 
zur Altägyptischen Kultur 36, pp.105-135, 2007.

[45] W. M. F. Petrie. Diopolis Parva: The Cemeteries of Abadiyeh and Hu, 1898-9, University Press, Oxford, 1901.

[46] J. Garstang. El-Arabah, a Cemetery of the Middle Kingdom: Survey of the Old Kingdom Temenos: Graffiti from the Temple of Sety, Bernard Quaritch, London, 1902.

[47] E. Naville. The XIth Dynasty Temple at Deir El-Bahari Part 1, Egypt Exploration Fund, London, 1907.

[48] The Earl of Carnarvon and H. Carter. Five Years' Explorations at Thebes: A Record of Work Done 1907-1911, Oxford University Press, London, 1912.

[49] T. E. Peet. Cemeteries of Abydos Part II.1911-1912, Egypt Exploration Fund, London, 1914.

[50] T. E. Peet and W. L. S. Loat. Cemeteries of Abydos Part III.1912-1913, Egypt Exploration Fund, London, 1914.

[51] G. Brunton. Qau and Badari I, British School of Archaeology in Egypt University College, London, 1927.

[52] G. Brunton. Qau and Badari II, British School of Archaeology in Egypt University College, London, 1928.

[53] H. Frankfort, H. 'The Cemeteries of Abydos: Work of the Season 1925-26', Journal of Egyptian Archaeology 16, pp.213-19, 1930 .

[54] E.S. Eaton. 'A Group of Middle Kingdom Jewellery'. Bulletin of the Museum of Fine Arts 39, pp.94-98, 1941.

[55] B. Kemp and R. Merrilees. Minoan Pottery in Second Millennium Egypt, Verlag Philipp von Zebern, Mainz am Rhein, 1980.

[56] C. Roehrig. 'The Middle Kingdom Tomb of Wah at Thebes', in N. Strudwick and J. H. Taylor (eds.) The Theben Necropolis: past, Present and Future, British Museum Publications, London, pp.11-13, 2003.

[57] J. Richards. Society and Death in Ancient Egypt: Mortuary Landscapes of Middle Kingdom, Cambridge University Press, Cambridge, 2005.

[58] A. Eggebrecht. Pelizaues-Museum in Hildesheim: die Ägyptische Sammlung, Verlag Philipp von Zabern, Mainz, 1993: 44, fig.34.

[59] A. Eggebrecht. Pelizaues-Museum in Hildesheim: die Ägyptische Sammlung, Verlag Philipp von Zabern, Mainz, 1993: 45 , fig. 35 .

[60] S. D'Auria, P. Lacovara, and C. H. Roehrig. Mummies and Magic: the Funerary Arts of Ancient Egypt, MFA Publications, Boston, 1988: 119.

[61] P. Lacau. Sarcophages antérieurs au Nouvel Empire vol.I, Imprimerie de l'institut Français, Cairo, 1904: 165-166.

[62] C. M. Firth and B. Gunn. Teti Pyramid Cemeteries, Imprimerie de l'institut Français, Cairo, 1926: p1.27A.
[63] M. Baba, and S. Yoshimura. 'Dahshur North: Intact Middle and New Kingdom Coffins', Egyptian Archaeology 37 (Autumn), pp.9-12, 2010: 10.

[64] F. Pellerin, M. Aubry, D. Percheron, J. Martinez, D. Castelain, M. Gautier and B. Girveau. Sésostris III Pharaon de Légende, Snoeck, Gand, 2014: 219.

[65] W. M. F. Petrie. Gizeh and Rifeh, Aris \& Phillips and Joel L. Malter, London, 1907: pl.11.

[66] R. David. The Two Brothers: Death and the Afterlife in Middle Kingdom Egypt, Rutherford Press, Bolton, 2007.

[67] E. F. Morris. 'Paddle Dolls and Performance', Journal of the American Research Center in Egypt 47, pp.71-103, 2011: fig.3.

[68] W. M. F. Petrie. Objects of Daily Use, Aris \& Phillips and Joel L. Malter, London, 1974 (1927): 59, fig.380.

[69] W. M. F. Petrie. Objects of Daily Use, Aris \& Phillips and Joel L. Malter, London, 1974 (1927): 59, fig.381.

[70] W. M. F. Petrie. Objects of Daily Use, Aris \& Phillips and Joel L. Malter, London, 1974 (1927): 59, fig.382.

[71] A. Lansing and W. C. Hayes. 'The Egyptian Expedition: The Excavations at Lisht', The Metropolitan Museum of Art Bulletin 29, pp.4-41, 1934: fig.29 (A).

[72] A. Lansing and W. C. Hayes. 'The Egyptian Expedition: The Excavations at Lisht', The Metropolitan Museum of Art Bulletin 29, pp.4-41, 1934: fig.29 (B).

[73] A. Lansing and W. C. Hayes. 'The Egyptian Expedition: The Excavations at Lisht', The Metropolitan Museum of Art Bulletin 29, pp.4-41, 1934: fig.29 (C).

[74] A. Lansing and W. C. Hayes. 'The Egyptian Expedition: The Excavations at Lisht', The Metropolitan Museum of Art Bulletin 29, pp.4-41, 1934: fig.29 (D).

[75] E. F. Morris. 'Paddle Dolls and Performance', Journal of the American Research Center in Egypt 47, pp.71-103, 2011: fig.8.

[76] W. M. F. Petrie. Objects of Daily Use, Aris \& Phillips and Joel L. Malter, London, 1974 (1927): 59, fig.390.

[77] W. M. F. Petrie. Objects of Daily Use, Aris \& Phillips and Joel L. Malter, London, 1974 (1927): 59, fig.391.

[78] H. E. Winlock. 'The Museum's Excavations at Thebes', The Metropolitan Museum of Art Bulletin 18, pp.11-39, 1923: 22, fig. 15 .

[79] E. F. Morris. 'Paddle Dolls and Performance', Journal of the American Research Center in Egypt 47, pp.71-103, 2011: 79 .

[80] G. Robins. Women in Ancient Egypt, The British Museum Press, London, 1993: fig.17a.

[81] J. Garstang. El-Arabah, a Cemetery of the Middle Kingdom: Survey of the Old Kingdom Temenos: Graffiti from the Temple of Sety, Bernard Quaritch, London, 1902: pl.26. 